7 Millar AB, Mitchell DM. Non-invasive investigation of pulmonary disease in patients positive for the human immunodeficiency virus. Thorax 1990;45:57-61.

8 Shaw RJ, Roussak C, Forster SM, Harris JW, Pinching AJ, Mitchell DM. Lung function abnormalities in patients with the human immunodeficiency virus with and without overt pneumonitis. Thorax 1988;43:436-40.
9 Kramer EL, Sanger JJ, Garay SM. Gallium-67 scans of the chest in patients with acquired immunodeficiency syndrome. F Nucl Med 1987;28:1107-14.

10 Kagawa FT, Kirsch CM, Yenokida GG, Levine ML. Serum lactate dehydrogenase activity in patients with AIDS and Pneumocystis carinii pneumonia. Chest 1988;94:1031-3.

\title{
Pulmonary physiology in St Swithin's Hole
}

The hospital photographer was an expert speleologist; his photographs of the inside of caves were quite remarkable. One morning he came to the physiology laboratory and asked if we could make him a breathing apparatus to explore under water the further end of a cave in the Mendips. This was before the days of an easily available aqualung. Using a small oxygen cylinder, rebreathing bag and a carbon dioxide absorber we soon had him walking up and down the bottom of the deep end of the local swimming pool.

I had never been caving before and the opportunity to join the party was too good to miss. There were three of us - two experts and me. We arrived at the site in the early morning and walked beside a small stream to where it seemed to disappear into the ground through a grating rather like a mud drain.

"This is where we go in," he said. The entrance was very narrow, and equipped with helmets, lights, food, and the breathing equipment, we squeezed in. The narrow entrance was very wet and we were soon soaked through. The cave's name was obvious.

It was a well used cave with rope ladders down the steep descents, and opened out into spectacular caves with magnificent rock formations. After about two hours we came to the "sump". This was where the cave went under water. It was about 12 feet long and a rope had been put through to assist our passage.

"A deep breath and a pull along the rope and you will be on the other side," he said. What I had not been told was that the floor rose as the roof came down so the opening was quite narrow. I was stuck with my knees on the bottom and my back on the top. The only thing was to go back. I did not panic.

"A second attempt will be easy," I was told, and it was.

We were now in the much less frequented part of the cave and pressed on to the object of our exploration where the cave again went under water. Our intrepid photographer donned his breathing apparatus and, with a rope around his middle, disappeared under water.

"One pull, let out more rope; two pulls, pull me back," he said. We gradually let out more rope. We felt a tug - or was it two? We pulled him back.

"What did you do that for?" he asked. "Let's try again."

He managed to penetrate about 20 feet into the cave with no evidence of where to surface and returned exhausted, mainly because the breathing apparatus could not cope with his hyperventilation under those conditions. A welcome meal and the trek back. I don't think I have ever been quite so tired. Climbing up a rope ladder with a waterfall pouring down your neck after six hours hard work is not easy. Coming out I lost my trousers in the narrow part of the cave. I could not care - my embarrassment of a walk through the village was saved by a thick fog which we found when we surfaced at last.

PETER J D HEAF 